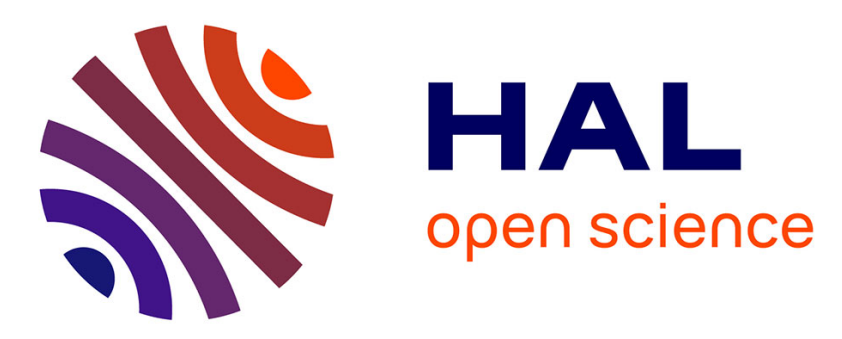

\title{
First paleoseismic evidence for great surface-rupturing earthquakes in the Bhutan Himalayas
}

Romain Le Roux-Mallouf, Matthieu Ferry, J.F. Ritz, Theo Berthet, Rodolphe Cattin, Dowchu Drukpa

\section{- To cite this version:}

Romain Le Roux-Mallouf, Matthieu Ferry, J.F. Ritz, Theo Berthet, Rodolphe Cattin, et al.. First paleoseismic evidence for great surface-rupturing earthquakes in the Bhutan Himalayas. Journal of Geophysical Research, 2016, 121 (10), pp.7271-7283. 10.1002/2015JB012733 . hal-01622276

\section{HAL Id: hal-01622276 https://hal.science/hal-01622276}

Submitted on 11 May 2021

HAL is a multi-disciplinary open access archive for the deposit and dissemination of scientific research documents, whether they are published or not. The documents may come from teaching and research institutions in France or abroad, or from public or private research centers.
L'archive ouverte pluridisciplinaire HAL, est destinée au dépôt et à la diffusion de documents scientifiques de niveau recherche, publiés ou non, émanant des établissements d'enseignement et de recherche français ou étrangers, des laboratoires publics ou privés. 


\section{Journal of Geophysical Research: Solid Earth}

\author{
RESEARCH ARTICLE \\ 10.1002/2015JB012733 \\ Key Points: \\ - Bhutan has been struck by at least two \\ great earthquakes over the last \\ millennium \\ - The present-day low-seismicity \\ rate observed in Bhutan is not \\ representative of the seismic activity \\ at a longer timescale \\ - $A M_{w} 9$ earthquake from central Nepal \\ to Assam between A.D. 1090 and A.D. \\ 1145 may satisfy all observations
}

Supporting Information:

- Supporting Information S1

\section{Correspondence to:}

R. Le Roux-Mallouf,

lerouxmallouf@gm.univ-montp2.fr

\section{Citation:}

Le Roux-Mallouf, R., M. Ferry, J.-F. Ritz,

T. Berthet, R. Cattin, and D. Drukpa

(2016), First paleoseismic evidence for great surface-rupturing earthquakes in the Bhutan Himalayas, J. Geophys. Res. Solid Earth, 121, 7271-7283, doi:10.1002/2015JB012733.

Received 11 DEC 2015 Accepted 14 SEP 2016 Published online 12 OCT 2016

\section{First paleoseismic evidence for great surface-rupturing earthquakes in the Bhutan Himalayas}

\author{
Romain Le Roux-Mallouf ${ }^{1}$, Matthieu Ferry ${ }^{1}$, Jean-François Ritz ${ }^{1}$, Théo Berthet ${ }^{2}$, Rodolphe Cattin ${ }^{1}$, \\ and Dowchu Drukpa ${ }^{3}$
}

${ }^{1}$ Géosciences Montpellier, CNRS, UMR5243, Université de Montpellier, Montpellier, France, ${ }^{2}$ Department of Earth Sciences, Uppsala University, Uppsala, Sweden, ${ }^{3}$ Seismology and Geophysics Division, Department of Geology and Mines, Thimphu, Bhutan

Abstract The seismic behavior of the Himalayan arc between central Nepal and Arunachal Pradesh remains poorly understood due to the lack of observations concerning the timing and size of past major and great earthquakes in Bhutan. We present here the first paleoseismic study along the Himalayan topographic front conducted at two sites in southern central Bhutan. Paleoseismological excavations and related OxCal modeling reveal that Bhutan experienced at least two great earthquakes in the last millennium: one between the seventeenth and eighteenth century and one during medieval times, producing a total cumulative vertical offset greater than $10 \mathrm{~m}$. Along with previous studies that reported similar medieval events in Central Nepal, Sikkim, and Assam, our investigations support the occurrence of either (i) a series of great earthquakes between A.D. 1025 and A.D. 1520 or (ii) a single giant earthquake between A.D. 1090 and A.D. 1145 . In the latter case, the surface rupture may have reached a total length of $\sim 800 \mathrm{~km}$ and could be associated with an earthquake of magnitude $M_{w}=8.7-9.1$.

\section{Introduction}

The Himalayan belt forms the boundary between the India Plate and the Tibetan plateau and is well known for its recent destructive earthquakes and elevated seismic hazard. However, the timing and size of major earthquakes that have struck this area over the last millennium remain poorly constrained. This is mostly due to uncertainties associated with the chronology, location, and magnitude of pretwentieth century Himalayan earthquakes, which allow a number of possible rupture scenarios.

In spite of an increasing number of paleoseismic studies carried out over the last decade [e.g., Lavé et al., 2005; Yule et al., 2006; Kumar et al., 2010; Mugnier et al., 2013; Bollinger et al., 2014; Rajendran et al., 2015], several areas remain poorly studied. This includes Bhutan, where the lack of observations leads to inconclusive results regarding the seismic behavior for this part of the Himalayas. Hence, the probability of occurrence of a $M_{w}=9$ earthquake in this region remains debated [Kumar et al., 2010; Mugnier et al., 2013; Srivastava et al., 2013; Stevens and Avouac, 2016]. On the one hand, Gahalaut et al. [2011] consider the Bhutan Himalaya as a zone of low seismic activity on the basis of the present-day seismicity. On the other hand, Kumar et al. [2010] infer the occurrence of a large medieval earthquake in Bhutan from paleoseismic investigations in Sikkim and Assam.

Here in order to test the possibility of such a great earthquake, we present paleoseismic investigations at two sites along the Himalayan front in Bhutan. After describing the Bhutan Himalaya setting, we summarize historical and geological observations of past major earthquakes in and nearby Bhutan. We then present the results of our paleoseismic investigation carried out in Central Bhutan. Our results, combined with previous studies, allow us to discuss the occurrence of major events in Bhutan and to propose two end-member scenarios for medieval earthquake rupture(s) along the Himalayan arc from central Nepal to Arunachal Pradesh.

\section{Seismotectonic Setting of Bhutan Himalaya}

\subsection{Geological Setting}

As is typical along the whole Himalayan arc, Bhutan can be divided into four distinct tectonic units in our study area [Gansser, 1964; Le Fort, 1975; McQuarrie et al., 2008; Long et al., 2011]: from north to south, the
(C2016. American Geophysical Union. All Rights Reserved. 
Table 1. Great Earthquakes Occurring Between Central Nepal and Arunachal Pradesh Over the Last Millennium

\begin{tabular}{|c|c|c|c|}
\hline Event & Location & Estimated Magnitude & Reference \\
\hline 2015 Gorkha $^{a}$ & $28.23^{\circ} \mathrm{N}-84.731^{\circ} \mathrm{E}$ & $M_{w} 7.8$ & $\begin{array}{c}\text { Avouac et al. [2015], Grandin et al. [2015], } \\
\text { and Wang and Fialko [2015] }\end{array}$ \\
\hline 1950 Assam a,b,c & $28.38^{\circ} \mathrm{N}-96.68^{\circ} \mathrm{E}$ & $M_{w} 8.6$ & $\begin{array}{c}\text { Ben-Menahem et al. [1974], Chen and Molnar [1977], } \\
\text { Triep and Sykes [1997], and Kumar et al. [2010] }\end{array}$ \\
\hline 1934 Bihar $^{\mathrm{b}, \mathrm{c}}$ & $26.86^{\circ} \mathrm{N}-86.59^{\circ} \mathrm{E}$ & $M_{w} \sim 8.0$ & $\begin{array}{c}\text { Chen and Molnar [1977], Ambraseys and Douglas [2004], } \\
\text { and Sapkota et al. [2013] }\end{array}$ \\
\hline 1833-1866 Kathmandu ${ }^{\mathrm{b}}$ & $27.7^{\circ} \mathrm{N}-85.7^{\circ} \mathrm{E}$ & $M_{w} \sim 7.5$ & $\begin{array}{c}\text { Bilham [1995], Rajendran and Rajendran [2005], } \\
\text { and Szeliga et al. [2010] }\end{array}$ \\
\hline 1713 Bhutan $^{\text {b }}$ & East Bhutan-Arunachal Pradesh & $?$ & $\begin{array}{c}\text { Jackson [2002], Ambraseys and Jackson [2003], } \\
\text { and Berthet et al. [2014] }\end{array}$ \\
\hline 1255 Kathmandu $^{\mathrm{b}, \mathrm{c}}$ & East Nepal & $?$ & $\begin{array}{l}\text { Pant [2002], Mugnier et al. [2013], Sapkota et al. [2013], } \\
\text { and Bollinger et al. [2014] }\end{array}$ \\
\hline 1100 Medieval earthquake(s) ${ }^{c}$ & $\begin{array}{l}\text { Central Nepal-East } \\
\text { Nepal-Sikkim-Assam }\end{array}$ & $\begin{array}{l}\text { Unique event or sequence } \\
\text { of ruptures? }\end{array}$ & $\begin{array}{c}\text { Nakata et al. [1998], Upreti et al. [2000], Lavé et al. [2005], } \\
\text { and Kumar et al. [2010] }\end{array}$ \\
\hline
\end{tabular}

\footnotetext{
${ }^{a}$ Instrumentally recorded.

${ }^{\mathrm{b}}$ Historically recorded.

'Paleoseismology study.
}

Tethyan Sedimentary Series (TSS), the Higher Himalaya (HH), the lesser Himalaya (LH), and the Siwaliks. The width of these units varies from Nepal to Bhutan. For instance, the LH is only a few kilometers wide in central Nepal and western Bhutan whereas it is tens of kilometers wide in Sikkim and East Bhutan. All these units are bounded by major faults including the South Tibetan Detachment (STD) to the north, the Main Central Thrust (MCT), the Main Boundary Thrust (MBT), and the Main Frontal Thrust (MFT) to the south, which is the most recent expression of the thrust sequence. While the MFT is well defined in Nepal and coincides with the present-day Himalayan topographic front, its location in Bhutan is less straightforward. The thrust fault that runs along the Bhutan/India border generally corresponds to the MFT, except in the Sarpang area where a 10 km wide reentrant feature directly juxtaposes LH and Quaternary alluvium [Long et al., 2011] (Figure 2). There, the most frontal structure expressed in the geomorphology is an anticline (Frontal Back Thrust) that likely accommodates a limited-though undetermined-fraction of the shortening [Dasgupta et al., 2013]. Its relationship to the main structures is yet to be explored. Within the reentrant, the main topographic scarp studied here corresponds structurally to the MBT or one of its splays and will be referred to as the Topographic Frontal Thrust (TFT) of Bhutan (Figure 2). South of the TFT is the foreland basin with recent sedimentary infill. At depth, the TFT and the three major north dipping MCT, MBT, and MFT root along the Main Himalayan Thrust (MHT), which is a midcrustal decollement where the India plate is underthrusted beneath the Himalayas and Tibet. Several studies suggest a ramp-flat-ramp-flat geometry for the MHT [e.g., Zhao et al., 1993; Nelson et al., 1996; Cattin and Avouac, 2000; Nábelek et al., 2009, Le Roux-Mallouf et al., 2015].

In central and east Nepal, the present-day shortening rate of $\sim 20 \mathrm{~mm} / \mathrm{yr}$ is associated with interseismic coupling on the MHT [e.g., Stevens and Avouac, 2015]. At longer timescales, fluvial terrace analyses [e.g., Lavé and Avouac, 2000] and tectonostratigraphic studies give a consistent rate, suggesting that the Nepal Himalaya absorbs about $20 \mathrm{~km} /$ Myr by localized thrusting since the Middle Miocene. In Bhutan, the presentday localization of deformation is only constrained by sparse GPS measurements in western Bhutan [Vernant et al., 2014] and a single estimate of Holocene uplift rate along the TFT in central Bhutan [Berthet et al., 2014].

Strain budget from past earthquakes reveals a deficit of seismic moment compared to the moment derived from geodetic measurements [e.g., Bilham et al., 2001; Stevens and Avouac, 2016]. This suggests the potential occurrence of several $M_{w} \geq 8.5$ earthquakes along the arc in the next few hundred years or a potential subduction-type $M_{w}=9$ earthquake [Kumar et al., 2010; Srivastava et al., 2013; Stevens and Avouac, 2016].

\subsection{Large Past Earthquakes}

Many large historical earthquakes have been documented along the Himalayan arc (Table 1). However, for Bhutan and regions nearby, information remains limited and partial. In the following, we will focus on the major earthquakes that have been documented within the study area between longitude $88^{\circ} \mathrm{N}$ and $93^{\circ} \mathrm{N}$ (Figure 1). 

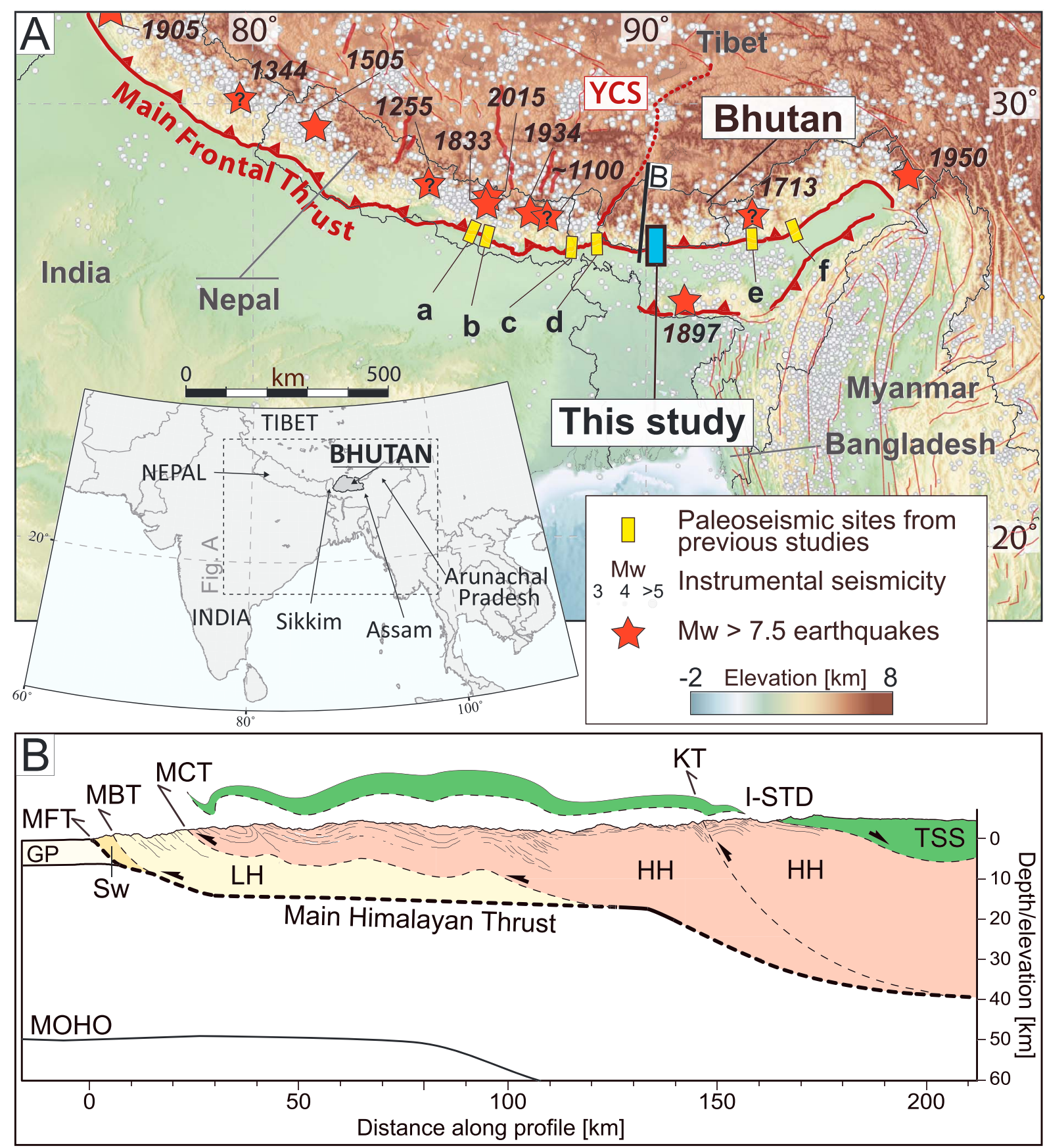

Figure 1. Location of the study area and regional context. (A) Inset shows the location of Bhutan along the Himalayan arc. Instrumental earthquakes of the Himalayan Arc are shown by open circles that show the instrumental seismicity $\left(M_{w}>3\right)$ between 1950 and 2015 . Red stars are epicenters of great and large earthquakes from instrumental data, surface damage, and paleoseismological investigations, queried where epicenter location is uncertain. Yellow rectangles are previous paleoseismological studies (a) Marha Khola [Lavé et al., 2005]; (b) Sir Khola [Sapkota et al., 2013]; (c) Hokse [Nakata et al., 1998; Upreti et al., 2000]; (d) Chalsa [Kumar et al., 2010]; (e) Nameri [Kumar et al., 2010]; (f) Harmutty [Kumar et al., 2010]. The blue rectangle is the location of this study. YCS = Yadong Cross Structure. (B) North-south simplified geological cross section across western Bhutan (modified after Grujic et al. [2011]). See Figure 1A for location, line B. Abbreviations are as follows: TSS, Tethyan Sedimentary Sequence; HH, Higher Himalayan; LH, Lesser Himalayan; Sw, Siwaliks sediments; GP, Ganga Plain; I-STD, Inner South Tibetan Detachment; KT, Kakhtang Thrust; MCT, Main Central Thrust; MBT, Main Boundary Thrust; TFT, Topographic Frontal Thrust; MFT, Main Frontal Thrust.

From instrumental and historical records, it appears that Bhutan has experienced no major earthquake in the past 200 years [Gahalaut et al., 2011]. The last major historical earthquake occurred in A.D. 1713, but its magnitude and location are poorly known. Described by a single Tibetan eyewitness traveling Bhutan, the event "destroyed all houses in all districts" and was reported in numerous contemporary Bhutanese sources 


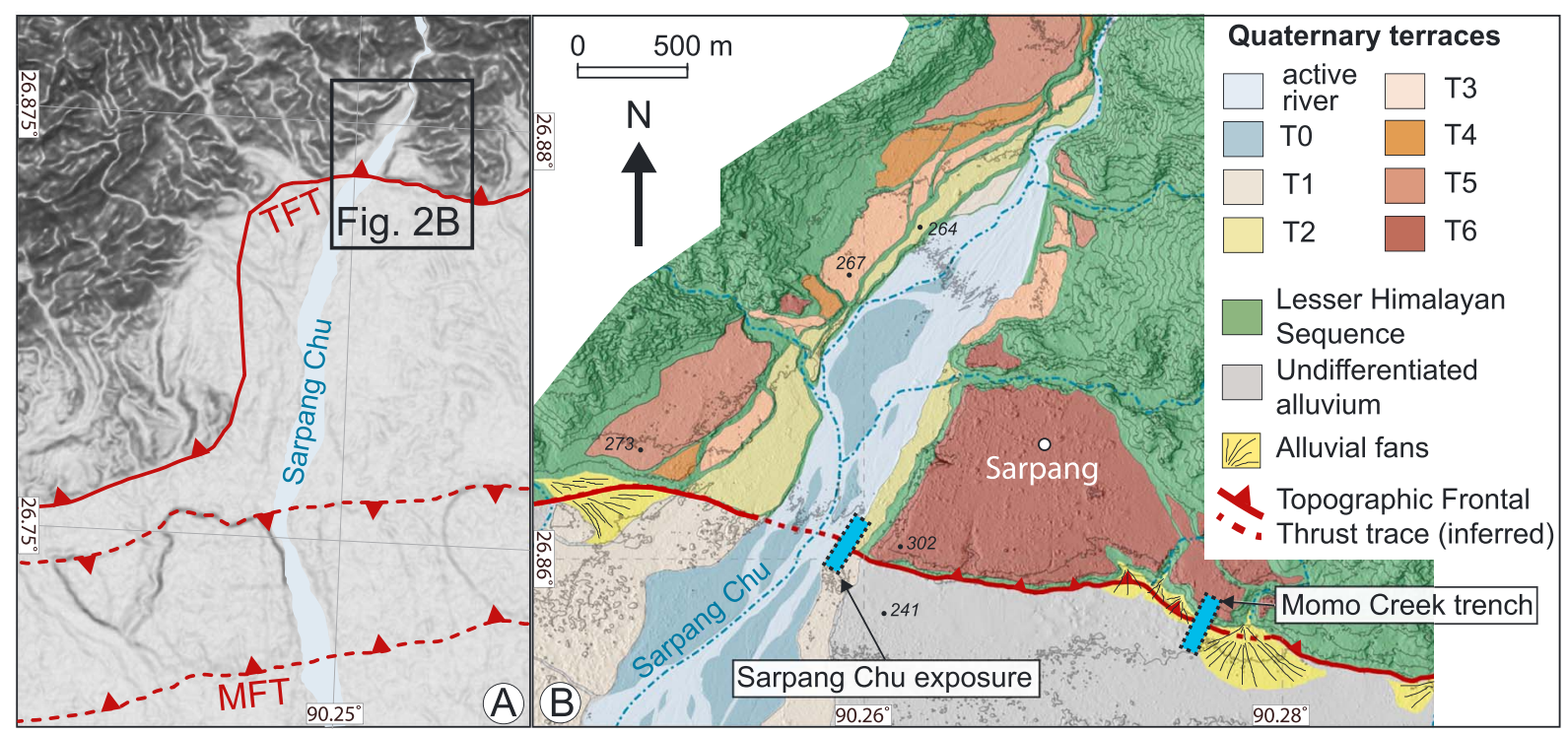

Figure 2. Geomorphological map of the Sarpang area. (a) Shaded map showing the position of the MFT and the TFT in the Sarpang area (DEM from SRTM 90 m). Black rectangle shows the position of the geomorphological study. (b) Geomorphological map of the Topographic Frontal Thrust, near the village of Sarpang, superimposed on $2 \mathrm{~m}$ resolution Pleiades Digital Elevation Model. Alluvial terraces are labeled from T0 (active channel) to T6 (oldest). Blue rectangles indicate the locations of the two trench sites (not to scale). Spacing of elevation contours is $20 \mathrm{~m}$. Black points indicate elevation values based on Pleiades DEM.

[Jackson, 2002]. On the basis of such "significance," Ambraseys and Jackson [2003] suggest a magnitude "probably approaching $M_{s} \sim 7 . "$ In nearby Arunachal Pradesh, an earthquake is also reported between A.D. 1696 and A.D. 1714, and the same authors propose that both accounts could reflect a single event in A.D. 1713. In light of the 2015 Gorkha earthquake sequence [Avouac et al., 2015], we consider it likely that the Bhutan and Arunachal Pradesh earthquakes are distinct events. Furthermore, since the A.D. 1713 earthquake is characterized by intense and widespread destruction over the territory of Bhutan, we conclude that its magnitude is greater than $M_{s}=7$ and its epicenter likely within the borders of Bhutan.

In Sikkim and Assam (i.e., immediately west and east of Bhutan), two trench sites reveal large-displacement events reaching as much as $18 \mathrm{~m}$ that occurred around A.D. 1100 [Kumar et al., 2010]. This event-or sequence of events-is also known at other paleoseismic sites. In the Marha Khola region of east central Nepal, Lavé et al. [2005] conclude that a large earthquake ruptured the MFT around A.D. 1100, with an estimated component of vertical offset of 7-7.5 m (and an inferred total coseismic displacement of 14-22 m). A prior trenching study at the border between Nepal and Sikkim suggests a coseismic displacement larger than $4 \mathrm{~m}$ associated with an event radiocarbon-dated to A.D. 1100-A.D. 1200 [Nakata et al., 1998, Upreti et al., 2000]. Assuming they are due to the same event, these paleoseimic observations suggest the occurrence of a great medieval earthquake, which had to affect Bhutan.

As previously mentioned, the information above is clearly insufficient to properly characterize past seismic ruptures in Bhutan. In the following, we present our approach to fill this data gap from paleoseismic investigations conducted in central Bhutan.

\section{Paleoseismological Analysis in Bhutan}

Following the study of Berthet et al. [2014], we focus our effort on two sites located in south central Bhutan, near the village of Sarpang, where the TFT cuts through Holocene deposits and uplifts a well-developed flight of fluvial terraces up to $\sim 50 \mathrm{~m}$ (T6 in Figure 2). Deformed Holocene features at this site include the following: (1) fluvial Holocene terraces associated with the Sarpang Chu (or Sarpang River) and (2) an alluvial fan deposited over the foot of the main tectonic scarp at Momo Creek. At both sites, we observed fault scarps several meters in height that indicate recent displacement across the TFT.

In order to define a chronostratigraphic framework, we collected 19 charcoal samples from the two sites. They were processed by the Poznan Radiocarbon Laboratory and resulting radiocarbon ages were calibrated using 


\begin{tabular}{|c|c|c|c|c|}
\hline Unit $^{\mathrm{a}}$ & Sample Name ${ }^{b}$ & Lab. No. $B^{c}$ & Measured Radiocarbon Age $^{d}$ & Calibrated Ages (Calendric, $2 \sigma)^{\mathrm{e}}$ \\
\hline \multicolumn{5}{|c|}{ Sarpang Chu } \\
\hline C & SC-02 & Poz-64699 & $940 \pm 30$ B.P. & Cal A.D. $1030-1160$ \\
\hline C & SC-03 & Poz-64700 & $1105 \pm 30$ B.P. & Cal A.D. $890-1010$ \\
\hline$C$ & SC-07 & Poz-64701 & $1000 \pm 80$ B.P. & Cal A.D. $890-1120$ \\
\hline B & SC-10 & Poz-64702 & $105 \pm 30$ B.P. & Cal A.D. $1680-1930$ \\
\hline B & SC-12 & Poz-64703 & $85 \pm 30$ B.P. & Cal A.D. $1690-1930$ \\
\hline B & SC-13 & Poz-64704 & $50 \pm 30$ B.P. & Cal A.D. $1690-1960$ \\
\hline B & SC-14 & Poz-64706 & $100 \pm 30$ B.P. & Cal A.D. $1680-1930$ \\
\hline C & SC-15 & Poz-64707 & $870 \pm 30$ B.P. & Cal A.D. $1050-1250$ \\
\hline C & SC-16 & Poz-64708 & $870 \pm 40$ B.P. & Cal A.D. $1040-1250$ \\
\hline B & P4-C06 & \multicolumn{2}{|c|}{ From Berthet et al. [2014] } & Cal A.D. $1490-1650$ \\
\hline B & P4-C07 & \multicolumn{2}{|c|}{ From Berthet et al. [2014] } & Cal A.D. $1420-1620$ \\
\hline \multicolumn{5}{|c|}{ Momo Creek } \\
\hline$E$ & MO-01 & Poz-64709 & $880 \pm 30$ B.P. & Cal A.D. $1040-1220$ \\
\hline$E$ & MO-02 & Poz-64710 & $880 \pm 30$ B.P. & Cal A.D. $1040-1220$ \\
\hline C & MO-04 & Poz-64711 & $225 \pm 30$ B.P. & Cal A.D. $1530-1800$ \\
\hline C & MO-05 & Poz-64712 & $320 \pm 35$ B.P. & Cal A.D. $1480-1650$ \\
\hline$E$ & MO-06 & Poz-64713 & $1165 \pm 30$ B.P. & Cal A.D. $770-970$ \\
\hline $\mathrm{E}$ & MO-07 & Poz-64755 & $880 \pm 30$ B.P. & Cal A.D. $1040-1220$ \\
\hline E & MO-10 & Poz-64756 & $1430 \pm 80$ B.P. & Cal A.D. $430-770$ \\
\hline$E$ & MO-11 & Poz-64757 & $3050 \pm 30$ B.P. & Cal B.C. $1400-1220$ \\
\hline B & MO-13 & Poz- 64758 & $145 \pm 30$ B.P. & Cal A.D. $1680-1950$ \\
\hline C & MO-16 & Poz-64759 & $360 \pm 40$ B.P. & Cal A.D. $1450-1640$ \\
\hline
\end{tabular}

\footnotetext{
${ }^{\mathrm{a}} \mathrm{See}$ trench logs for stratigraphic unit designations.

${ }^{\mathrm{b}}$ The two sites are indicated by SC for Sarpang Chu and MO for Momo Creek.

CLaboratory sample codes. All samples have been dated by the Poznan Radiocarbon Laboratory.

d Radiocarbon years B.P. relative to 1950 A.D. (with $1 \sigma$ counting error).

${ }^{\mathrm{e}}$ Calendric dates were calibrated using $\mathrm{OxCal}$ and the atmospheric calibration curve IntCal13. Calendric ages have been rounded to the nearest $1 / 2$ decade assuming the 5 years accuracy of the IntCal 13 curve.
}

OxCal 4.2 [Bronk Ramsey, 2009] with the IntCal13 calibration curve [Reimer et al., 2013] (Table 2). Charcoal samples yield radiocarbon ages older than that of the sediment in which they deposited (reflecting fluvial transport and sample location within the original tree section) and therefore maximum ages for the host layer. We account for potential inheritance of up to 200 years by building into our OxCal model an outlier model [Bronk Ramsey, 2009; Barnett et al., 2015]. Inheritance sensitivity tests result in a marginal variation in the range of 10 years; hence, we prefer relying on the original age distributions that are directly comparable to nearby paleoseismic sites for which inheritance was not implemented. Additionally, we attempt to limit the effect of inheritance by favoring study sites with geomorphological contexts indicative of short transport time (i.e., scarp-controlled watershed basins), consider charcoal-derived ages as a lower bound for the associated deposit and assess variability by processing as many as three distinct samples per unit, wherever possible.

\subsection{Sarpang Chu}

The Sarpang Chu site $\left(26.860893^{\circ} \mathrm{N}, 90.258855^{\circ} \mathrm{E}\right)$ is a $\sim 6 \mathrm{~m}$ high topographic scarp where a river-cut cliff exposes a shallow north dipping thrust fault zone between an abandoned fluvial terrace and modern alluvium (Figure 3a). We extended the natural exposure to a depth of $1.5 \mathrm{~m}$ below the water level. The scarp influences local drainages and guides a lateral tributary toward the Sarpang Chu (Figure 3a).

The photomosaic and associated trench log (Figures $3 b$ and $3 c$ ) document the main lithological units that we defined in the field: in the hanging wall (northern side) the deepest exposed unit G is a highly deformed, massive, pale purple phyllite that corresponds to the Paleozoic Baxa formation (Lesser Himalayan sequence in Long et al. [2011]). It is only exposed near the northern end of the outcrop and is overlain by a $3 \mathrm{~m}$ thick openwork, clast-supported alluvial gravel unit $\mathrm{D}$, which comprises well-rounded pebbles and cobbles in a sandy matrix. Unit $D$ is overlain by a distinct fine sand to silt unit that we interpret as an overbank deposit (unit B). Unit D is exposed near the base of the trench on the footwall (southern side), and we interpret it as a fluvial deposit from the Sarpang Chu. There, it is overlain by the $2.5 \mathrm{~m}$ thick fine-grained sand unit C, typical of a low-energy alluvial deposit. In cross section, unit $C$ reveals sand channels associated with the 


\section{AGU. Journal of Geophysical Research: Solid Earth}

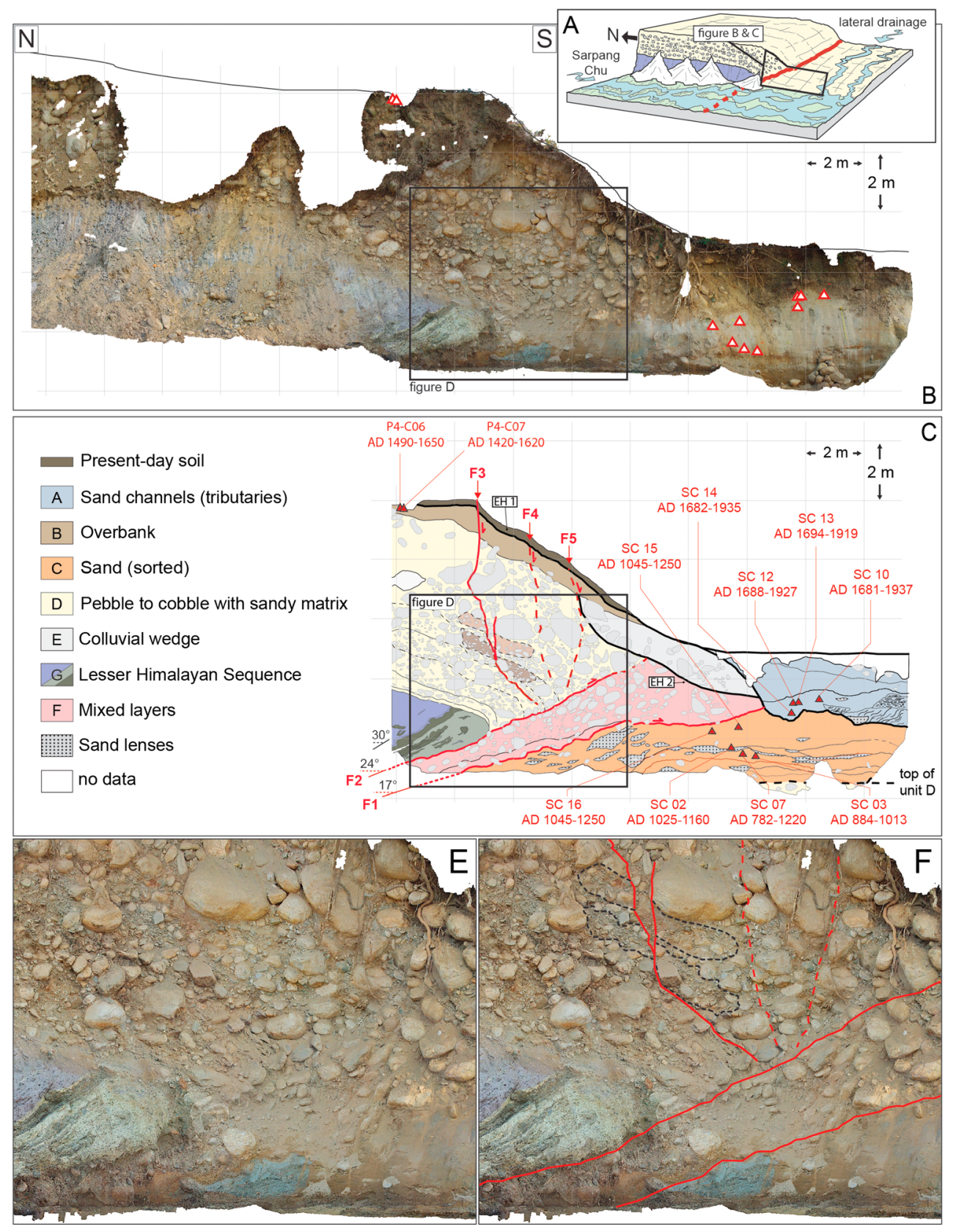

Figure 3. Sarpang Chu paleoseismic site. (a) Block diagram showing geomorphic context of the Sarpang Chu site. Black Q7 polygon shows the area that we logged in detail. (b) Orthorectified photomosaic of the left bank of the Sarpang Chu. Triangles indicate the locations and 2 $\sigma$-calibrated calendar ages of 11 detrital charcoal samples (including P4-C06 and P4C07 from Berthet et al. [2014]). (c) Detailed log over a $2 \mathrm{~m}$ grid. Solid and dashed red lines are main faults (respectively certain and suspected). Thick black lines labeled "EH 1" and "EH 2" are the event horizons. (d) Enlarged orthophotography of the deformation zone showing sheared sediments within the fault zone. (e) Interpretation of the enlarged orthophotography of the deformation zone.

tributary drainage controlled by the topographic scarp. Large-scale observations show a shear zone that juxtaposes units $G$ and $D$ on the northern side against units $D$ and $C$ on the southern side along a $1 \mathrm{~m}$ wide deformation zone composed of sheared sand and gravel (unit F). It is limited by faults $\mathrm{F} 2$ and F1 dipping $24^{\circ} \mathrm{N}$ and $17^{\circ} \mathrm{N}$, respectively (Figure $3 \mathrm{C}$ ). This shear zone is truncated within its upper part (notably within the F2 strand) and sealed by unit $E$, which we interpret as scarp-derived colluvium from unit $D$. This feature corresponds to a fault termination criteria sealed by a colluvial wedge unit [e.g., Kumar et al., 2010; Sapkota et al., 2013] 


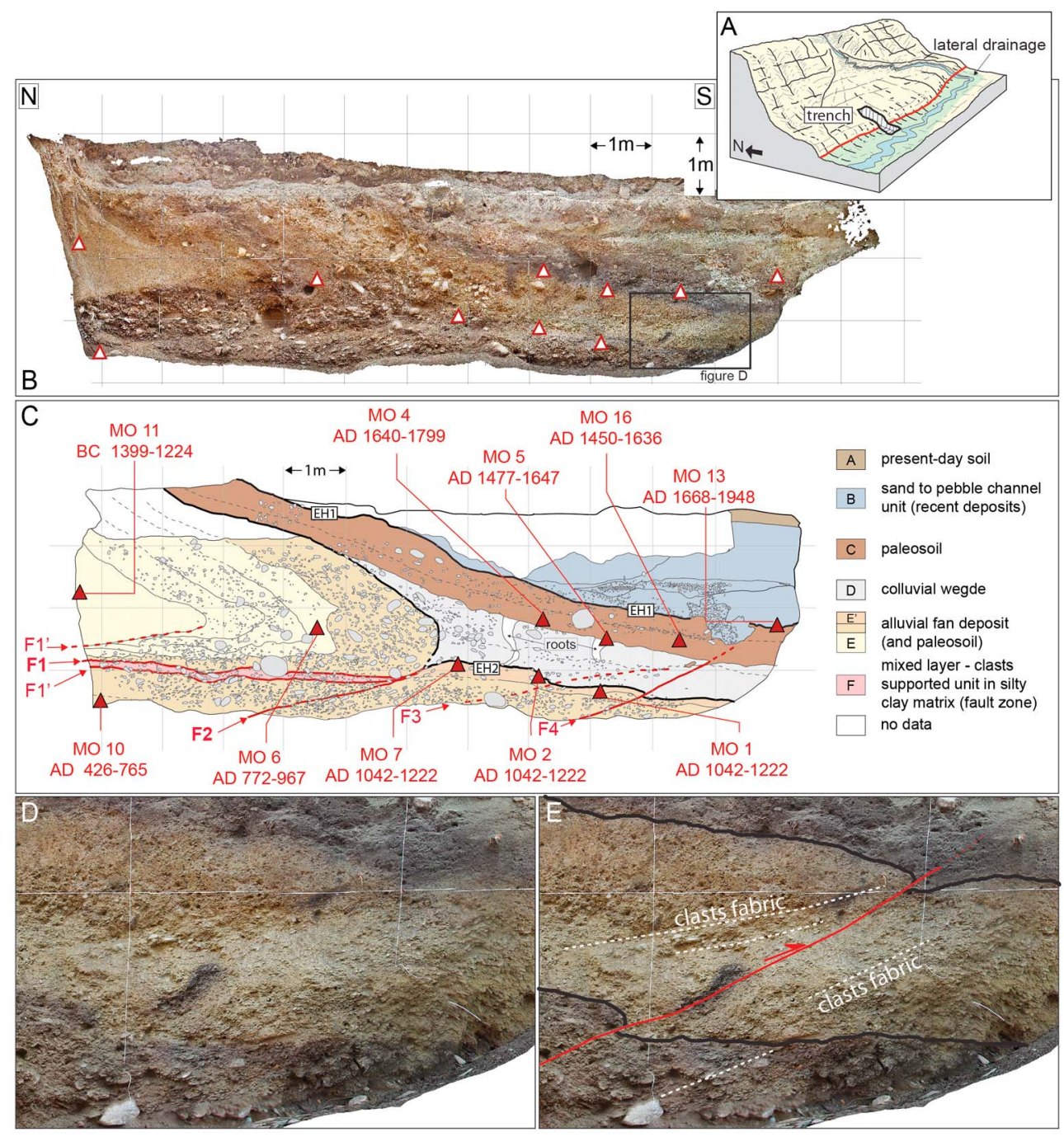

Figure 4. Momo Creek paleoseismic site. (a) Block diagram showing geomorphic context of the Momo Creek site. Black polygon shows the area that we logged in detail. (b) Orthorectified photomosaic of the eastern wall of the trench. Triangles indicate the locations and $2 \sigma$-calibrated calendar ages of 10 detrital charcoals samples. (c) Detailed log of the eastern wall over a $1 \mathrm{~m}$ grid. Solid and dashed red lines are main faults. Heavy black lines labeled "EH 1" and "EH 2" are the event horizons. (d) Enlarged orthophotography showing (i) the deformation of units E, E', D, and C across F3 and (ii) the Q8 shear texture within the unit D. (e) Interpretation of the enlarged orthophotography of the deformation zone.

indicating that a surface-rupturing earthquake occurred between the time of deposition of Units $C$ and $D$ (see event horizon EH2 in Figure 3c).

Within the hanging wall, near-vertical normal fault strand $F 3$ offsets units $D$ and $B$ vertically by about $0.5 \mathrm{~m}$ and connects to the main fault zone. Unit $\mathrm{G}$ forms a competent indenter driven along $\mathrm{F} 2$ and into the unconsolidated unit D. We propose that slip along F2 induces uplift above the tip of the indenter and collapse ahead of it. Hence, $\mathrm{F} 3$ limits such collapse zone that may be associated to either a small coseismic displacement along the upper $\mathrm{F} 2$ (event 1 ) or a small-scale mass movement induced by the development of the free face. The deformation event is predated by unit $B$ and postdated by unit $A$.

We collected charcoal samples from units A, B [from Berthet et al., 2014], and C for radiocarbon dating that yielded ages between A.D. 782 and A.D. 1937 (Table 2). Considering that (1) a small catchment implies short transport for charcoals sampled in units A and C (Figure 2) and (2) charcoal samples within the same stratigraphic unit yield similar radiocarbon ages (Table 2), we assume the charcoals are not significantly older than the depositional age. Using the methodology proposed by Lienkaemper and Bronk Ramsey [2009] for 


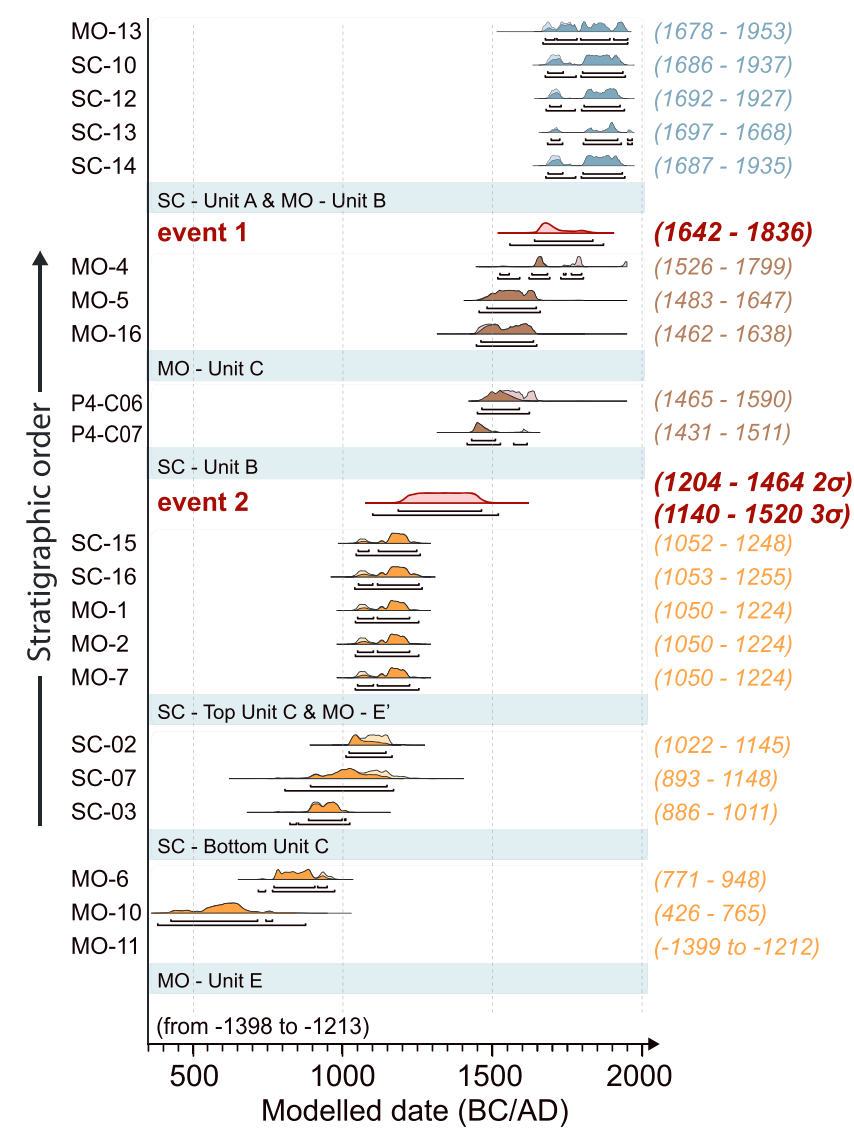

Figure 5. OxCal chronostratigraphic model for surface-rupturing events 1 and 2 inferred from the two paleoseismic sites. The model is built from (1) the stratigraphic information on associated faulted and unfaulted layers and (2) 20 detrital charcoal samples (including P4-C06 and P4-C07 from Berthet et al. [2014]). The different colors indicate charcoals within the same phase: orange dates predate the event 2 ; brown postdate the event 2 and predate the event 1 ; blue postdate the event 1 . with smaller angular clasts consistent with a nearby source (Figures $4 \mathrm{~b}$ and $4 \mathrm{c}$ ). The occurrence of rare boulders show that the watershed basin of Momo Creek includes material eroded from alluvial terrace T6 (Figure 2). The oldest exposed unit (E) is a massive sequence of matrix-supported, poorly sorted, and poorly rounded cobble to pebble layers associated with alluvial fan deposition. Over the southern side of the trench, the unit is capped by a thin $(\sim 10 \mathrm{~cm})$ paleosol (unit $\left.E^{\prime}\right)$. The whole unit is folded and offset along faults $\mathrm{F} 1$ and F2. Faults F1 and F2 are overlain by a wedge-shaped unit (D) composed of silty sand with rare gravel layers. Units $E$ and $D$ form a topographic scarp that is covered by an organic-rich $70 \mathrm{~cm}$ thick paleosol, unit (C). At the base of the scarp, Unit $C$ is buried by unit $B$ that is composed of small gravel and sand channels deposited by a tributary stream that drains along the scarp (Figures $4 a$ and $4 c$ ). The uppermost unit $A$ is the $20 \mathrm{~cm}$ thick modern soil.

The trench exposes (Figure 4c) a fault propagation fold developed in unit $\mathrm{E}$ by motion along fault F1. The upper part of the fold forms a $4.4 \pm 0.5 \mathrm{~m}$ high topographic scarp, which is buried by colluvial wedge Unit $D$, derived from unit $E$. This indicates that a surface-rupturing earthquake (event 2 ) occurred after unit $E / E^{\prime}$ formed and prior to the deposition of colluvial wedge unit D. Considering the geometry and lithology of unit $\mathrm{E}$, we propose (i) a minimum of $6 \mathrm{~m}$ of relative displacement of the fold nose, including the thickening of the nose fold and the shearing and thinning of the base of the unit. Because the northern termination of the fold is not visible in the trench, we propose the total of $6 \mathrm{~m}$ as a minimum value of coseismic slip for event 2 (Figure S8). 


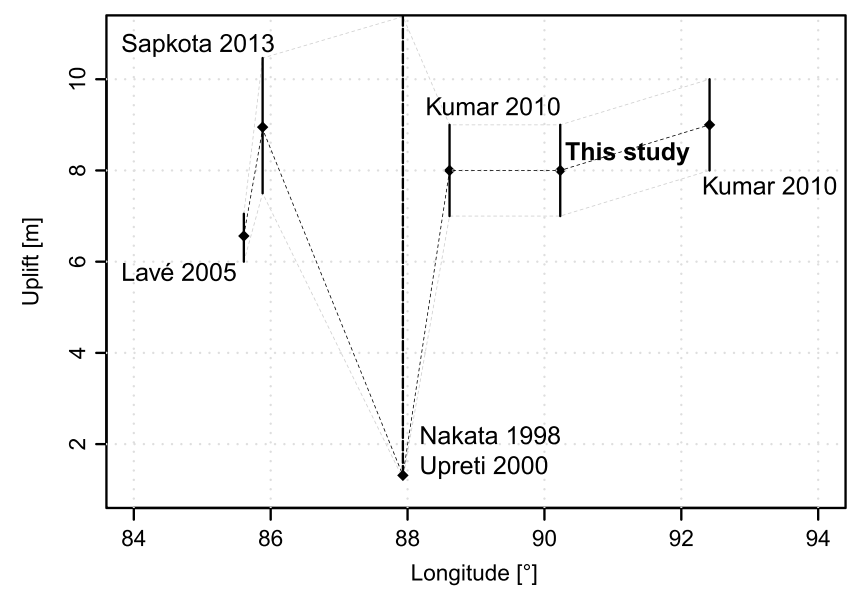

Figure 6. Distribution of coseismic uplift for medieval surface ruptures from Nakata et al. [1998], Upreti et al. [2000], Lavé et al. [2005], Kumar et al. [2010], and Sapkota et al. [2013] along the Himalayan arc. Coseismic uplift estimated from paleoseimic studies and scarp heights. Upreti et al.'s uplift (heavy dashed line) is calculated using (1) a minimum of $4 \mathrm{~m}$ of coseismic slip and (2) an average of dip angle derived from the other trenches used in this study. Black and grey dashed lines connecting to the points correspond to the coseismic slip value and associated uncertainties envelopes.
South of F2, unit E/E' exhibits a step-like geometry and is affected by F3 and F4. Fault F3 is attested by warping of the stratigraphic contact between units $E / E$ ' and D prolonged by a diffuse shear zone within unit $D$. At the southern end of the exposed section, F4 is more clearly expressed by shearing within units $E / E^{\prime}$ and $\sim 10 \mathrm{~cm}$ offset of the base and top of unit D (Figure 4). Overall, these relatively subtle features define a significantly smaller second event (event 1), which occurred after or during the development of unit $C$ and before unit B was deposited. At this site, the rupture associated with this first event may not have fully reached the surface or with minimal geomorphic expression.

We collected 10 charcoal samples from units $E, C$, and $B$ to constrain the ages of the units (Table 2). Considering that (1) units $E, C$, and $B$ derive from a small catchment (Figure 2), (2) samples collected within the same stratigraphic unit yield similar radiocarbon ages (Table 2), and (3) the relationships between samples chronology, stratigraphy, and events closely reflects observations from the Sarpang site, we assume negligible inheritance in the radiocarbon ages. The OxCal stratigraphic model for the Momo Creek trench suggests that the second event occurred between A.D. 1179 and A.D. 1547 and that the tentative first event occurred between A.D. 1650 and A.D. 1910 (Table 2). The total vertical offset recorded by unit $\mathrm{E}$ between the undeformed bottom layer at $3.5 \mathrm{~m}$ depth inside the trench and the top of the scarp at $4.4 \pm 0.5 \mathrm{~m}$ is about $8 \mathrm{~m}$. Because the first event appears to contribute little to this cumulative value, we consider that $8 \mathrm{~m}$ approximates the vertical displacement associated with event 2.

The two events identified at Momo Creek are consistent with the two events identified at Sarpang Chu in terms of timing and coseismic slip. Though evidence for event 1 is subtle and its tectonic origin may not be fully attested at Sarpang Chu, its occurrence is supported by similar observations within a different stratigraphic setting at Momo Creek. Hence, we propose that event 1 may correspond to a relatively smaller surface-rupturing earthquake along the TFT. Consequently, we build an OxCal stratigraphic model (Figure 5) combining stratigraphy and age constraints and abutting relationships from both trench exposures. This allows bracketing the occurrence of event 2 between A.D. 1140 and A.D. $1520(3 \sigma)$ and the occurrence of possible event 1 between A.D. 1642 and A.D. $1836(2 \sigma)$.

\section{Discussion}

Paleoseismological investigations conducted at two different sites along the TFT in the Sarpang area yield consistent results for both age and vertical offset associated with at least one major earthquake that occurred in Bhutan over the last millennium. Our observations suggest that a great earthquake occurred between A.D. 1140 and A.D. 1520 with $~ 8 \mathrm{~m}$ of vertical offset. A second event may have occurred between A.D. 1642 and A. D. 1836 and was associated with up to $0.5 \mathrm{~m}$ of vertical offset. Thirty kilometers to the east, Berthet et al. [2014] find comparable values for an alluvial terrace dated to A.D. $1150 \pm 100$ and uplifted by $7.9 \pm 0.5 \mathrm{~m}$.

\subsection{The Seventeenth to Eighteenth Century Earthquake}

Our study suggests that the most recent event (event 1) along the TFT in Bhutan may have occurred between A.D. 1642 and A.D. 1836 with a weak surface expression suggestive of a relatively low magnitude or a distant hypocenter. Based on the historical record, the only known earthquake that could correspond to this event is 


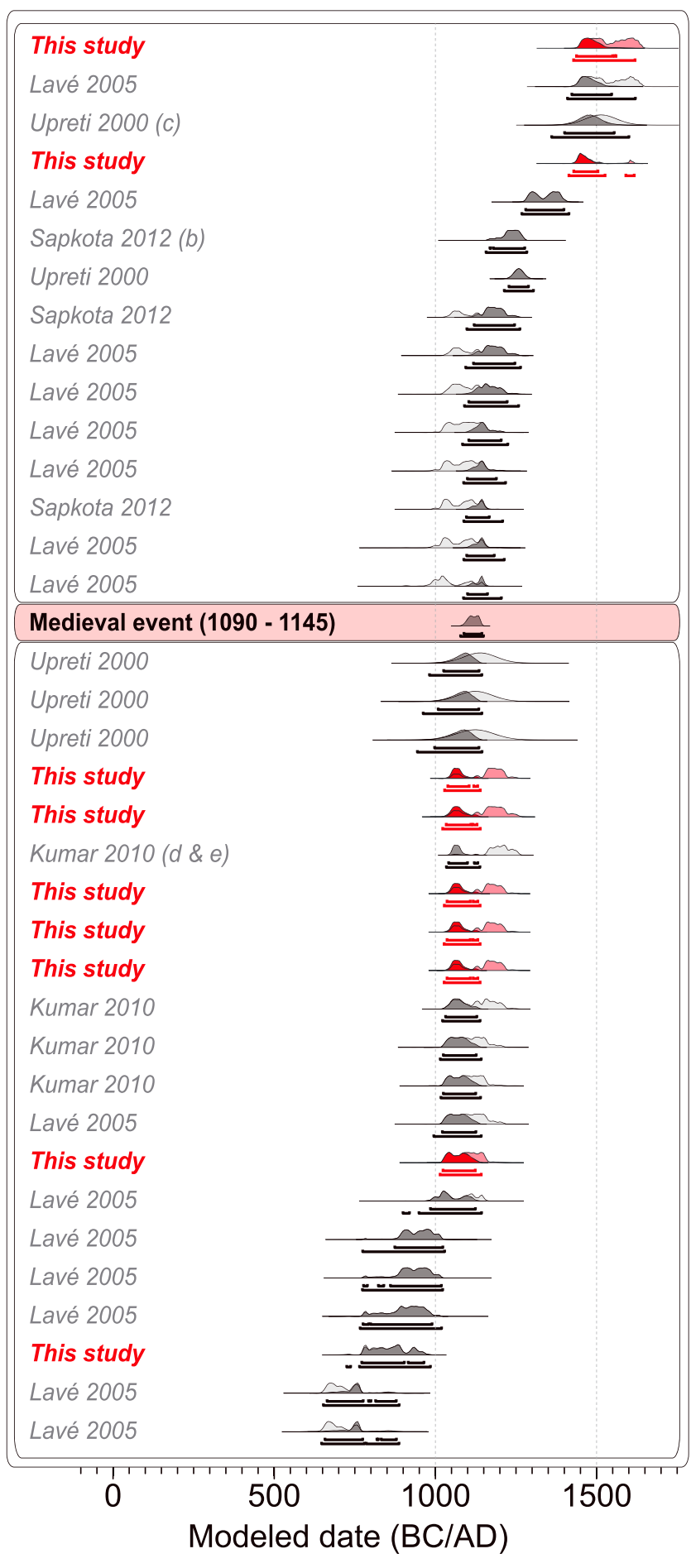

Figure 7. OxCal chronostratigraphic model for a single surface-rupturing event along the Himalayan arc yields a $2 \sigma$ of occurrence between A.D. 1090 and A.D. 1145. Grey and pink distributions correspond to the probability of ages for each sample. Black and red distributions correspond to modeled ages that take into account the stratigraphic constraints. The calibrated ages and the stratigraphical model are built from (1) radiocarbon age data from Nakata et al. [1998], Upreti et al. [2000], Lavé et al. [2005], Kumar et al. [2010], and Sapkota et al. [2013] and (2) abutting relationships regarding faulted (older than the medieval event) and unfaulted (younger than the medieval event) layers. the A.D. 1713 earthquake that "destroyed all houses in all districts" and occurred "somewhere in Bhutan or in Arunachal Pradesh" [Jackson, 2002; Ambraseys and Jackson, 2003].

We consider three possibilities. First, assuming that this event is a $M_{s} \sim 7$ earthquake as proposed by Ambraseys and Jackson [2003], this suggests that the actual epicenter is probably farther west in central Bhutan, closer to our study sites. Second, if the epicenter is reasonably well located $\sim 200 \mathrm{~km}$ east of our study sites, the magnitude of this event may have been significantly underestimated. Lastly, neither the magnitude nor the location is adequately determined by historical data. Presently, the scarcity of data available on that earthquake does not allow discriminating between these scenarios. However, the small coseismic slip measured for event 1 is consistent with the relatively low magnitude proposed for the A.D. 1713 earthquake.

\subsection{The Medieval Earthquake in Bhutan}

The penultimate event (event 2) occurred during a period for which historical records are scarce. The only known historical earthquake that occurred during this period is the A.D. 1255 earthquake in central Nepal (see section 2). In parallel, on the basis of a paleoseismic study aimed at complementing historical records, Lavé et al. [2005] propose another great earthquake may have occurred along the MFT at $\sim$ A.D. 1100. Uncertainties associated with radiocarbon dating do not allow us to determine to which earthquake our event 2 should be associated.

Our study suggests a coseismic vertical offset of $\sim 8 \mathrm{~m}$ for event 2 . According to the fault bend folding model proposed by Lavé and Avouac [2000] and a dip of $40^{\circ}$ to $60^{\circ}$ for the TFT deduced from dip measurements from the nearby Baxa formation [Long et al., 2011b], this would result from $9 \mathrm{~m}$ to $13 \mathrm{~m}$ of coseismic dip slip at depth. In the Sarpang Chu exposure, where the fault juxtaposes 


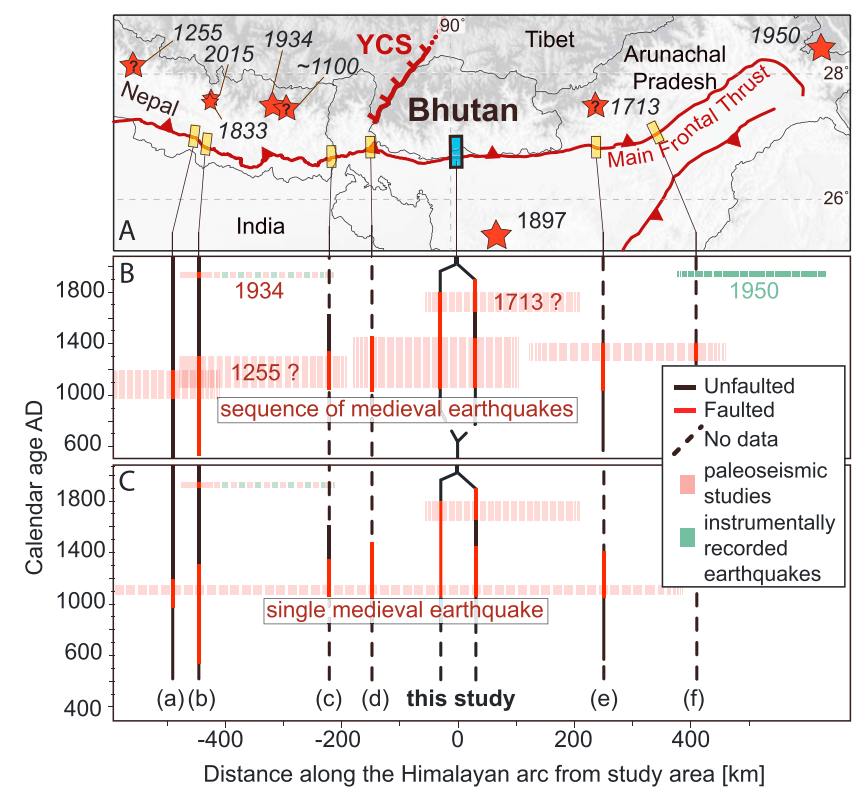

Figure 8. Summary of paleoseismic investigations. (a) Map showing estimated locations of great earthquakes (red stars) and paleoseismological investigations along the MFT/TFT in the Nepal-Sikkim-Bhutan area. Yellow rectangles are the locations of previous paleoseismological studies [Lavé et al., 2005; Sapkota et al., 2013; Nakata et al., 1998; Upreti et al., 2000; Kumar et al., 2010]. Blue rectangle indicates location of sites studied here (Sarpang Chu and Momo Creek). YCS = Yadong Cross Structure. (b) Space-time diagram showing modeled constraints on the timing of occurrence of surface-rupturing earthquakes for a sequence of medieval great earthquakes. Vertical axis is time in calendar years A.D., horizontal axis is kilometers from our study area. Red and green approximate constraints in terms of length and timing from paleoseismological and instrumental studies, respectively. Faulted and unfaulted segments come from paleoseismic data developed by a range of different authors. (c) Space-time diagram showing radiocarbon-modeled constraints on timing of occurrence for the scenario of a single regional event between A.D. 1090 and A.D. 1145 with a $95.4 \%$ probability. the Baxa formation and Holocene alluvium, observed dips of $20^{\circ}$ to $30^{\circ}$ yield 16 to $23 \mathrm{~m}$ of coseismic dip slip at the surface. This would represent some of the largest values observed along continental faults worldwide and may only be compared to subduction-type earthquakes [Blaser et al., 2010]. They are, however, observed systematically in the Central Himalaya, the Indian Sikkim and Assam [Lavé et al., 2005; Kumar et al., 2010; Bollinger et al., 2014]. Figure 6 shows measured coseismic uplift for medieval surface-rupturing events along that section of the arc with values ranging consistently between $4 \mathrm{~m}$ and $12 \mathrm{~m}$. Uplift to dip-slip conversion relies either (1) on trench observations where the free surface induces fault refraction and the dip often is extremely small or (2) on nearby structural measurements reflecting the dip values at a lower depth. Hence, uncertainties on dip-slip values are noticeably larger and yield coseismic slip values ranging from $10 \mathrm{~m}$ to $30 \mathrm{~m}$.

Determining an associated magnitude may as well involve uncertainties as such amounts of coseismic slip are rarely documented in databases used to derive scaling laws [e.g., Wells and Coppersmith, 1994; Shaw and Scholz, 2001, and references therein]. For instance, Dmax - L functions proposed by Manighetti et al. [2007] for mature faults saturate above $\sim 8 \mathrm{~m}$ and an associated $\sim 500 \mathrm{~km}$ long rupture. According to Leonard [2010], the 16-23 $\mathrm{m}$ of coseismic slip derived at Sarpang Chu corresponds to $M_{w} \sim 8.7$ (for the maximum value). Since coseismic slip and age constraints are consistent across several contiguous paleoseismic studies along the Himalayas, we propose two end-member hypotheses: (1) the large estimate of vertical offset is a local phenomenon and the rupture zone of this earthquake is limited to one segment of the MFT, likely part of a sequence or (2) event 2 is part of the same earthquake rupture that is documented elsewhere along the Himalayan arc during this time period. We test and further discuss these two end-member hypotheses in light of previous paleoseismic studies along the Himalayan Arc between central Nepal and eastern Bhutan.

\subsection{Scenarios for Medieval Earthquake(s) Sequence}

We revisit original data from trench studies by Nakata et al. [1998], Upreti et al. [2000], Lavé et al. [2005], Kumar et al. [2010], and Sapkota et al. [2013]. We build OxCal stratigraphic models for each section to update calibrated dates and provide consistent radiocarbon age calibration and event identification (Figures 7, S3-S7, and Tables S1-S9).

Our calculations demonstrate that both the single great earthquake hypothesis and the multiple earthquake hypothesis are consistent with the whole data set (Figure 7). Using age constraints from all published paleoseismological trenches, and regardless of favored values and historical a priori, we show that the single-event model implies the occurrence of a great earthquake between A.D. 1090 and A.D. 1145 with a $95.4 \%$ probability with respect to the data set (Figures 7 and 8). We note that this model yields a single 
age distribution and rejects the A.D. 1255 earthquake as a potential candidate in favor of the $\sim$ A.D. 1100 event. Following relationships from Leonard [2010] with (i) an average coseismic slip of 10-20 m [Nakata et al., 1998; Upreti et al., 2000; Lavé et al., 2005; Kumar et al., 2010; Sapkota et al., 2013], (ii) a locked zone of $\sim 100 \mathrm{~km}$ in width [Vernant et al., 2014], and (iii) a full rupture with a surface length ranging from $500 \mathrm{~km}$ (Bhutan to West Arunachal Pradesh) to $800 \mathrm{~km}$ (Central Nepal to Assam), this great medieval earthquake may have reached $M_{w}=8.7-9.1$.

\section{Conclusions}

Our results demonstrate that Bhutan has experienced at least one great earthquake over the last millennium. This points out that the present-day low seismicity rate observed in Bhutan is not representative of the seismic activity at a longer timescale.

First, we conclude that a large earthquake may have occurred in Central Bhutan in the seventeenth to eighteenth century. Assuming that the event is the A.D. 1713 earthquake and considering historical accounts, it may be associated with a 200 to $300 \mathrm{~km}$ long rupture from Bhutan to Arunachal Pradesh. Such events, comparable to the $2015 M_{w}=7.8$ Gorka earthquake in Nepal [Avouac et al., 2015], contribute little to the deformation budget and exhibit subtle-if any-expression in surface exposures [Angster et al., 2015]. However, their large magnitude and shallow depth yield intense ground motion and a concerning potential for destruction that calls for extensive studies [Grandin et al., 2015].

Second, we identify an older far larger earthquake that would have produced $\sim 8 \mathrm{~m}$ of coseismic uplift (16-23 $\mathrm{m}$ of coseismic surface slip) in medieval times with an inferred $M_{w} \sim 8.7$. A comparable event is observed at numerous trench sites in Central Nepal, Sikkim, and Assam and may be part either of a series of great single-segment earthquakes between A.D. 1025 and A.D. 1520 or of one even greater multisegment earthquake that ruptured from central Nepal to Assam between A.D. 1090 and A.D. 1145 with $M_{w}=8.7-9.1$.

In a densely populated region exposed to intense natural disasters, these results point out the necessity to document past large to great earthquakes in terms of chronology, coseismic slip, and rupture extent to properly assess seismic hazard for the whole Himalayan Arc.

\section{Acknowledgments}

This project is funded by the French Agence Nationale de la Recherche (ANR-13-BS06-0006-01), the CNES/ISIS program, and the CNES/TOSCA program. R.L.M. PhD is supported by a fellowship from the French Ministry for Higher education and Research. We would like to thank all the people who helped in the fieldwork, particularly our drivers Phajo Kinley and Tsheten from the Department of Geology and Mines. We would like to thank Stéphane Mazzotti who helped us improve and clarify the manuscript. We also thank Serge Lallemand for constructive comments and three anonymous reviewers for detailed and constructive comments that improved the quality of this contribution. Supporting data are included in an SI file. Correspondence and requests for materials should be addressed to lerouxmallouf@gm.univmontp2.fr

\section{References}

Ambraseys, N., and D. Jackson (2003), A note on early earthquakes in northern India and southern Tibet, Curr. Sci., 84, 570-582.

Ambraseys, N. N., and J. Douglas (2004), Magnitude calibration of north earthquakes, Geophys. J. Int., 159, 165-206.

Angster, S., E. J. Fielding, S. Wesnousky, I. Pierce, D. Chamlagain, D. Gautam, B.-N. Upreti, Y. Kumahara, and T. Nakata (2015), Field reconnaissance after the 25 April 2015 M 7.8 Gorkha earthquake, Seismol. Res. Lett., 86(6), 1506-1513.

Avouac, J.-P., L. Meng, S. Wei, T. Wang, and J.-P. Ampuero (2015), Lower edge of locked Main Himalayan Thrust unzipped by the 2015 Gorkha earthquake, Nat. Geosci., 8(9), 708-711, doi:10.1038/ngeo2518.

Barnett, E. A., B. L. Sherrod, J. F. Hughes, H. M. Kelsey, J. L. Czajkowski, T. J. Walsh, T. A. Contreras, E. R. Schermer, and R. J. Carson (2015), Paleoseismic evidence for late Holocene tectonic deformation along the Saddle Mountain fault zone, southeastern Olympic peninsula, Washington, Bull. Seismol. Soc. Am., 105, 38-71, doi:10.1785/0120140086.

Ben-Menahem, A., E. Aboodi, and R. Schild (1974), The source of the great Assam earthquake-An interplate wedge motion, Phys. Earth Planet. Inter., 9(4), 265-289, doi:10.1016/0031-9201(74)90056-9.

Berthet, T., J. F. Ritz, M. Ferry, P. Pelgay, R. Cattin, D. Drukpa, R. Braucher, and G. Hetényi (2014), Active tectonics of the eastern Himalaya: New constraints from the first tectonic geomorphology study in southern Bhutan, Geology, 42(5), 427-430, doi:10.1130/G35162.1.

Blaser, L., F. Krüger, M. Ohrnberger, and F. Scherbaum (2010), Scaling relations of earthquake source parameter estimates with special focus on subduction environment, Bull. Seismol. Soc. Am., 100(6), 2914-2926, doi:10.1785/0120100111.

Bilham, R. (1995), Location and magnitude of the 1833 Nepal earthquake and its relation to the rupture zones of contiguous great Himalayan earthquakes, Curr. Sci., 69(2), 101-128.

Bilham, R., V. K. Gaur, and P. Molnar (2001), Himalayan seismic hazard, Science, 293(5534), 1442-1444.

Bollinger, L., S. N. Sapkota, P. Tapponnier, Y. Klinger, M. Rizza, J. Van der Woerd, D. R. Tiwari, R. Pandey, A. Bitri, and S. Bes de Berc (2014), Estimating the return times of great Himalayan earthquakes in eastern Nepal: Evidence from the Patu and Bardibas strands of the Main Frontal Thrust, J. Geophys. Res. Solid Earth, 119, 7123-7163, doi:10.1002/2014JB010970.

Bronk Ramsey, C. (2009), Bayesian analysis of radiocarbon dates, Radiocarbon, 51(1), 337-360.

Cattin, R., and J. P. Avouac (2000), Modeling mountain building and the seismic cycle in the Himalaya of Nepal, J. Geophys. Res., 105(B6), 13,389-13,407, doi:10.1029/2000JB900032.

Chen, W. P., and P. Molnar (1977), Seismic moments of major earthquakes and the average rate of slip in central Asia, J. Geophys. Res., 82(20), 2945-2969, doi:10.1029/JB082i020p02945.

Dasgupta, S., K. Mazumdar, L. H. Moirangcha, T. D. Gupta, and B. Mukhopadhyay (2013), Seismic landscape from Sarpang re-entrant, Bhutan Himalaya foredeep, Assam, India: Constraints from geomorphology and geology, Tectonophysics, 592, $130-140$.

Gahalaut, V. K., S. Rajput, and B. Kundu (2011), Low seismicity in the Bhutan Himalaya and the stress shadow of the 1897 Shillong Plateau earthquake, Phys. Earth Planet. Inter., 186(3), 97-102.

Gansser, A. (1964), Geology of the Himalaya(s), Geol. Mag., 104(01), 86, doi:10.1017/S0016756800040450. 
Grandin, R., M. Vallée, C. Satriano, R. Lacassin, Y. Klinger, M. Simoes, and L. Bollinger (2015), Rupture process of the $M_{w}=7.92015$ Gorkha earthquake (Nepal): Insights into Himalayan megathrust segmentation, Geophys. Res. Lett., 42, 8373-8382, doi:10.1002/ 2015GL066044.

Grujic, D., C. J. Warren, and J. L. Wooden (2011), Rapid synconvergent exhumation of Miocene-aged lower orogenic crust in the eastern Himalaya, Lithosphere, 3(5), 346-366, doi:10.1130/L154.1.

Jackson, D. (2002), The Great Western-Himalayan Earthquake of 1505: A Rupture of the Central Himalayan Gap? pp. 147-159, Brill's Tibetan Studies Library I, Leiden.

Kumar, S., S. G. Wesnousky, R. Jayangondaperumal, T. Nakata, Y. Kumahara, and V. Singh (2010), Paleoseismological evidence of surface faulting along the northeastern Himalayan front, India: Timing, size, and spatial extent of great earthquakes, J. Geophys. Res., 115, B12422, doi:10.1029/2009JB006789.

Lavé, J., and J. P. Avouac (2000), Active folding of fluvial terraces across the Siwaliks Hills, Himalayas of central Nepal, J. Geophys. Res., 105(B3), 5735-5770.

Lavé, J., D. Yule, S. Sapkota, K. Basant, C. Madden, M. Attal, and R. Pandey (2005), Evidence for a great medieval earthquake ( 1100 A.D.) in the central Himalayas, Nepal, Science, 307(5713), 1302-1305, doi:10.1126/science.1104804.

Le Fort, P. (1975), Himalaya: The collided range. Present knowledge of the continental arc, Am. J. Sci., 275, 1-44.

Leonard, M. (2010), Earthquake fault scaling: Self-consistent relating of rupture length, width, average displacement, and moment release, Bull. Seismol. Soc. Am., 100(5A), 1971-1988.

Le Roux-Mallouf, R., et al. (2015), Evidence for a wide and gently dipping Main Himalayan Thrust in western Bhutan, Geophys. Res. Lett., 42, 3257-3265, doi:10.1002/2015GL063767.

Lienkaemper, J. J., and C. Bronk Ramsey (2009), OxCal: Versatile tool for developing paleoearthquake chronologies-A primer, Seismol. Res. Lett., 80(3), 431-434, doi:10.1785/gssrl.80.3.431.

Long, S., N. McQuarrie, T. Tobgay, D. Grujic, and L. Hollister (2011), Geologic map of Bhutan, J. Maps, 7(1), 184-192, doi:10.4113/ jom.2011.1159.

Long, S., N. McQuarrie, T. Tobgay, and D. Grujic (2011b), Geometry and crustal shortening of the Himalayan fold-thrust belt, eastern and central Bhutan, Geol. Soc. Am. Bull., 123, B30203-1.

Manighetti, I., M. Campillo, S. Bouley, and F. Cotton (2007), Earthquake scaling, fault segmentation, and structural maturity, Earth Planet. Sci. Lett., 253(3), 429-438.

McQuarrie, N., D. Robinson, S. Long, T. Tobgay, D. Grujic, G. Gehrels, and M. Ducea (2008), Preliminary stratigraphic and structural architecture of Bhutan: Implications for the along strike architecture of the Himalayan system, Earth Planet. Sci. Lett., 272(1), 105-117, doi:10.1016/ j.epsl.2008.04.030

Mugnier, J.-L., A. Gajurel, P. Huyghe, R. Jayangandaperumal, F. Jouanne, and B. Upreti (2013), Structural interpretation of the great earthquakes of the last millennium in the central Himalaya, Earth Sci. Rev., 127, 30-47, doi:10.1016/j.earscirev.2013.09.003.

Nábelek, J., G. Hetényi, J. Vergne, S. Sapkota, B. Kafle, M. Jiang, H. Su, J. Chen, B.-S. Huang, and H.-C. Team (2009), Underplating in the Himalaya-Tibet collision zone revealed by the Hi-CLIMB experiment, Science, 325(5946), 1371-1374, doi:10.1126/science.1167719.

Nakata, T., K. Kumura, and T. Rockwell (1998), First successful paleoseismic trench study on active faults in the Himalaya, Eos Trans. AGU, 79, 45.

Nelson, K. D., et al. (1996), Partially molten middle crust beneath southern Tibet: Synthesis of project INDEPTH results, Science, 274(5293), 1684-1688.

Pant, M. R. (2002), A step toward a historical seismicity of Nepal, Adarsa, 2, 29-60.

Rajendran, C. P., and K. Rajendran (2005), The status of central seismic gap: A perspective based on the spatial and temporal aspects of the large Himalayan earthquakes, Tectonophysics, 395(1), 19-39, doi:10.1016/j.tecto.2004.09.009.

Rajendran, C. P., B. John, and K. Rajendran (2015), Medieval pulse of great earthquakes in the central Himalaya: Viewing past activities on the frontal thrust, J. Geophys. Res. Solid Earth, 120, 1623-1641, doi:10.1002/2014JB011015.

Reimer, P. J., et al. (2013), IntCal13 and Marine13 radiocarbon age calibration curves 0-50,000 years cal BP, Radiocarbon, 55, 1869-1887, doi:10.2458/azu_js_rc.55.16947.

Sapkota, S. N., L. Bollinger, Y. Klinger, P. Tapponnier, Y. Gaudemer, and D. Tiwari (2013), Primary surface ruptures of the great Himalayan earthquakes in 1934 and 1255, Nat. Geosci., 6(2), 71-76, doi:10.1038/ngeo1669.

Shaw, B. E., and C. H. Scholz (2001), Slip-length scaling in large earthquakes: Observations and theory and implications for earthquake physics, Geophys. Res. Lett., 28(15), 2995-2998, doi:10.1029/2000GL012762.

Srivastava, H. N., B. K. Bansal, and M. Verma (2013), Largest earthquake in Himalaya: An appraisal, J. Geol. Soc. India, 82(1), 15-22.

Stevens, V. L., and J. P. Avouac (2015), Interseismic coupling on the main Himalayan thrust, Geophys. Res. Lett., 42, 5828-5837, doi:10.1002/ 2015 GL064845.

Stevens, V. L., and J.-P. Avouac (2016), Millenary $M_{w}>9.0$ earthquakes required by geodetic strain in the Himalaya, Geophys. Res. Lett., 43 , 1118-1123, doi:10.1002/2015GL067336.

Szeliga, W., S. Hough, S. Martin, and R. Bilham (2010), Intensity, magnitude, location and attenuation in India for felt earthquakes since 1762 Bull. Seism. Soc. Amer., 100(2), 570-584, doi:10.1785/0120080329.

Triep, E. G., and L. R. Sykes (1997), Frequency of occurrence of moderate to great earthquakes in intracontinental regions: Implications for changes in stress, earthquake prediction, and hazards assessments, J. Geophys. Res., 102(B5), 9923-9948, doi:10.1029/96JB03900.

Upreti, B. N., T. Nakata, Y. Kumahara, H. Yagi, K. Okumura, T. K. Rockwell, N. S. Virdi, and H. Maemoku (2000), The latest active faulting in southeast Nepal, in Proceedings of the Hokudan International Symposium and School in Active Faulting, pp. 533-536.

Vernant, P., R. Bilham, W. Szeliga, D. Drupka, S. Kalita, A. K. Bhattacharyya, V. K. Gaur, P. Pelgay, R. Cattin, and T. Berthet (2014), Clockwise rotation of the Brahmaputra Valley relative to India: Tectonic convergence in the eastern Himalaya, Naga Hills, and Shillong Plateau, J. Geophys. Res. Solid Earth, 119, 6558-6571.

Wang, K., and Y. Fialko (2015), Slip model of the $2015 M_{w} 7.8$ Gorkha (Nepal) earthquake from inversions of ALOS-2 and GPS data, Geophys. Res. Lett., 42, 7452-7458, doi:10.1002/2015GL065201.

Wells, D. L., and K. J. Coppersmith (1994), New empirical relationships among magnitude, rupture length, rupture width, rupture area, and surface displacement, Bull. Seismol. Soc. Am., 84(4), 974-1002.

Yule, D., J. Lave, S. N. Sapkota, D. Tiwari, B. Kafle, M. R. Pandey, S. Dawson, C. Madden, and M. Attal (2006), Large surface rupture of the Main Frontal Thrust in east-central and western Nepal-Evidence for an unprecedented type of Himalayan earthquake, Proceedings on the International Workshop on Seismology, seismotectonics and seismic hazard in the Himalayan region, Kathmandu, 28-29 November, 2006, 13-14.534.

Zhao, W., K. D. Nelson, J. Che, J. Quo, D. Lu, C. Wu, and X. Liu (1993), Deep seismic reflection evidence for continental underthrusting beneath southern Tibet, Nature, 366(6455), 557-559. 